\title{
PENINGKATAN HASIL BELAJAR MATEMATIKA SISWA KELAS VI MELALUI PENERAPAN MEDIA VIDEO ANIMASI
}

\author{
DWINA PERMATA SARI \\ SD Negeri 32 Prabumulih \\ E-mail : $\underline{\text { dwinapermatasari86@gmail.com }}$
}

\begin{abstract}
ABSTRAK
Penelitian ini bertujuan untuk meningkatkan kemampuan peserta didik kelas VI SD Negeri 32 Prabumulih dalam memahami materi Operasi Hitung Pecahan pada pembelajaran matematika dengan menggunakan media Video Animasi Penelitian ini merupakan penelitian tindakan kelas yang terdiri atas 2 (dua) siklus yang setiap siklus terdiri atas 4 (empat) tahapan. Siklus I dan II masing-masing terdiri dari 3 kali pertemuan. Subyek penelitian terdiri dari siswa kelas VI SD Negeri 32 prabumulih. Data kemampuan peserta didik dalam memahami operasi hitung pecahan dikumpulkan dengan menggunakan lembar observasi dan tes.Berdasarkan hasil analisis data, diperoleh rata-rata nilai post test pada siklus pertama adalah 70,24dengan persentase siswa yang mencapai Kriteria Ketuntasan Minimum (KKM) sebesar 67\%. Pada siklus kedua diperoleh rata-rata nilai post test adalah 83,57 dengan persentase siswa yang mencapai Kriteria Ketuntasan Minimum (KKM) sebesar $86 \%$. Hasil penelitian menunjukkan bahwa penerapan media video animasi berpengaruh terhadap peningkatan hasil belajar matematika materi operasi hitung pecahan.
\end{abstract}

Kata Kunci: Video Animasi, Hasil Belajar, Media Pembelajaran

\section{PENDAHULUAN}

Pada umumnya pembelajaran matematika baik di tingkat dasar maupun menengah masih dianggap sebagai mata pelajaran yang sulit dipahami oleh siswa sehingga siswa terlebih dahulu takut terhadap mata pelajaran matematika. Hasil temuan pada saat observasi menunjukkan bahwa masih banyak siswa sekolah dasar kesulitan memahami pelajaran matematika. Seperti yang terjadi pada siswa kelas VI SDN 32 Prabumulih Sumatera Selatan, berdasarkan hasil rerata prasiklus yang dilakukan penulis, dari 21 siswa hanya $29 \%$ siswa memdapatkan nilai di atas 70 , sedangkan $71 \%$ mendapatkan nilai di bawah 70 . Hal ini menunjukkan belum tercapainya kriteria ketuntasan minimal (KKM) yang telah ditetapkan oleh sekolah yaitu 70. Hal ini terjadi dikarenakan terdapat beberapa kendala, antara lain kurangnya minat siswa dalam belajar, kurang menariknya kegiatan pembelajaran sehingga meminimalisir motivasi siswa dalam belajar, dan kurangnya penggunaan media dalam pembelajaran.

Salah satu upaya untuk meningkatkan kualitas pembelajaran matematika di kelas, guru dapat menggunakan media yang disesuaikan dengan gaya belajar yang dimiliki oleh siswa (Ferry, dkk. 2019). Menurut Nusir (2012:13) mengatakan bahwa penggunaan program interaktif multimedia sangat efektif dalam meningkatkan keterampilan atau kemampuan siswa dalam belajar Matematika dasar, karena anak-anak akan termotivasi oleh grafis dan animasi khususnya ketika karakter kartun yang mereka kenal digunakan pada permainan dalam pembelajaran. Selain itu, terdapat beberapa manfaat media pembelajaran diantaranya: pengajaran akan lebih menarik perhatian siswa sehingga dapat dipahami lebih oleh siswa, metode mengajar akan dipahami lebih oleh siswa, metode mengajar akan lebih bervariasi, siswa lebih banyak melakukan kegiatan belajar, sebab tidak hanya mendengar uraian guru, tetapi juga aktivitas lain seperti mengamati, melakukan, dan lain sebagainya (Sudjana, 2005).

Dalam belajar matematika, siswa-siswa mempunyai gaya belajarnya sendiri. Gaya belajar merupakan potensi dasar atau kecenderungan potensi anak. Dalam merancang pembelajaran, baik itu strategi, metode, media pembelajaran dan aktivitas-aktivitas yang melibatkan peserta didik, guru harus memperhatikan beberapa gaya belajar yang berbeda- 
Vol. 1 No. 1 Mei 2021

beda yang dimiliki oleh siswa. Gaya belajar secara umum dibagi menjadi visual, auditorial, dan kinestetik. Perbedaan gaya belajar dapat menunjukkan cara terbaik bagi siswa untuk menyerap informasi lebih cepat. Sebagai seorang guru bisa memahami bagaimana gaya belajar peserta didik, mungkin akan lebih mudah dalam menentukan strategi dalam proses pembelajaran dan bisa memberikan hasil yang maksimal (Deporter dan Hernacki, 2005; Ferry, 2019).

Media yang digunakan dalam penelitian ini adalah video animasi. Penerapan media animasi dalam pembelajaran memiliki hubungan signifikan terhadap perhatian, ketertarikan, motivasi, serta hal lainnya yang ada pada siswa (Anwar, Liliawati dan Utama, 2013). Minat belajar yang tinggi berawal dari motivasi diri pada siswa itu sendiri sehingga berpengaruh positif terhadap hasil belajar, (Nurhasanah, 2016).

Pemecahan masalah yang digunakan adalah dengan menggunakan media video animasi yang diharapkan dapat memotivasi siswa dan meningkatkan minat siswa untuk belajar sehingga berdampak pada peningkatan hasil belajar siswa.

\section{METODE PENELITIAN}

Jenis penelitian yang digunakan adalah Penelitian Tindakan Kelas (PTK) dimana suatu kegiatan penelitian ilmiah yang dilakukan secara rasional, sistematis dan empiris terhadap berbagai tindakan yang dilakukan sejak disusunnya suatu perencanaan sampai penilaian terhadap tindakan nyata didalam kelas yang berupa kegiatan belajar mengajar, untuk memperbaiki dan meningkatkan kondisi pembelajaran yang dilakukan. Subjek penelitian ini adalah siswa kelas VISD Negeri 32 Prabumulih. Penelitian Tindakan Kelas ini dilaksanakan dari tanggal 24 Agustus s/d 07 September 2020. Rancangan yang digunakan adalah model rancangan dengan menggunakan dua siklus, dengan masing-masing siklus terdiri dari empat tahapan yaituperencanaan, tindakan, observasi dan evaluasi, dan refleksi (Stephen Kemmis dan MC. Taggart, 1988; Somawati, 2019).

Berikut ini adalah rancangan penelitian tindakan kelas yang disajikan seperti pada gambar 1 :

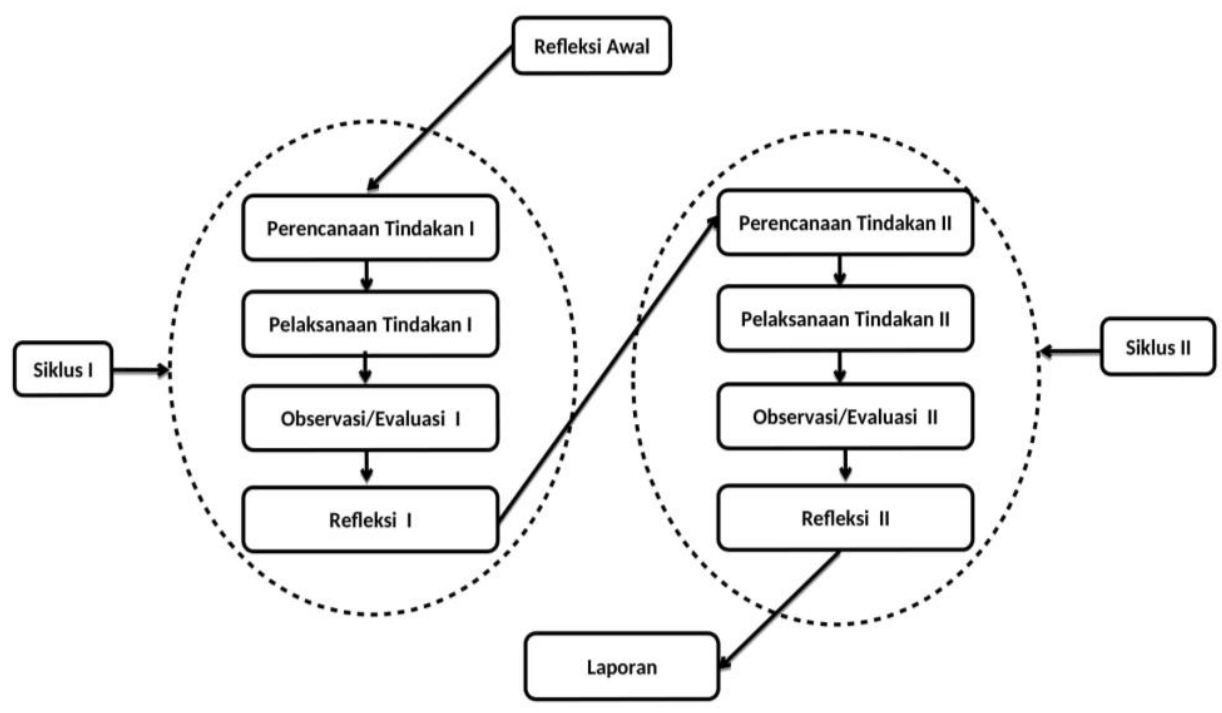

Gambar 1. Rancangan Penelitian tindakan kelas

Pada siklus Iterdiri dari beberapatahapan yaitu: tahap (1) Perencanaan Yang meliputi pembuatan rencana pembelajaran, menyiapkan pedoman observasi keaktifan siswa, berkonsultasi dengan teman sejawat untuk membuat instrumen, dan mengkondisikan siswa agar dapat mengikuti pembelajaran dengan baik. Tahap (2) Pelaksanaan, merupakan kegiatan tindakan dilakukan dengan pembelajaran dikelas. Pada tahap ini, guru peneliti telah menyiapkan instrumen yang akan digunakan, guru peneliti menggunakan aplikasi zoom 
meeting yang akan diikuti oleh teman sejawat, serta seluruh siswa dengan menggunakan metode daring berbantu media berupa video animasi yang akan di tampilkan di layar yang dapat disaksikan oleh seluruh siswa.Tahap (3), Pada tahap ini, pengamatan dilakukan pada waktu tindakan sedang berjalan. Jadi keduanya berlangsung pada waktu yang sama. Pada tahap ini, guru yang bertindak sebagai peneliti melakukan pengamatan dan mencatat semua hal yang diperlukan dan terjadi selama pelaksanaan tindakan berlangsung. Pengumpulan data ini dilakukan dengan menggunakan belajar yang telah tersusun, termasuk juga pengamatan secara cermat pelaksanaan skenario tindakan dari waktu ke waktu serta dampaknya terhadap proses dan hasil belajar siswa. Tahap (4) Tahapan ini dimaksudkan untuk mengkaji secara menyeluruh tindakan yang telah dilakukan, berdasarkan data yang telah terkumpul, kemudian dilakukan evaluasi guna menyempurnakan tindakan berikutnya. Refleksi dalam PTK mencakup análisis, síntesis, dan penilaian terhadap hasil pengamatan atas tindakan yang dilakukan. Jika terdapat masalah dari proses refleksi maka dilakukan proses pengkajian ulang melalui siklus berikutnya yang meliputi kegiatan: perencanaan ulang, tindakan ulang, dan pengamatan ulang sehingga permasalahan dapat teratasi.

Pada pelaksanaan siklus II, proses pembelajaran yang dilakukan pada siklus ini meliputi: Tahap (1) Peneliti membuat rencana pembelajaran, menyiapkan pedoman observasi keaktifan siswa, berkonsultasi dengan teman sejawat untuk membuat instrumen Pada tahap menyusun rancangan diupayakan merupakan rancangan yang dibuat berdasarkan hasil perbaikan dari kelemahan pada siklus I. Tahap (2) guru peneliti menggunakan aplikasi zoom meeting yang akan diikuti oleh teman sejawat, serta seluruh siswa dengan menggunakan metode daring berbantu media berupa yang video animasi yang akan di tampilkan di layar yang dapat disaksikan oleh seluruh siswa. Tahap (3) melakukan pengamatan yang meliputi mengobservasi aktivitas belajar peserta didik selama proses pembelajaran, mengevaluasi proses pembelajaran. Selanjutnya tahap (4) melakukan refleksi tentang hasil aktivitas belajar peserta didik selama proses pembelajaran dan post test (tes akhir belajar) pada akhir siklus yang akan dilakukan dengan menggunakan google form.

\section{HASIL DAN PEMBAHASAN}

\section{a. Hasil Penelitian}

Sebelum peneliti melakukan perbaikan pembelajaran, peneliti melakukan kegiatan prasiklus. Pada kegiatan prasiklus, guru menyampaikan materi tanpa menggunakan media apapun dan hanya menggunakan metode ceramah. Selanjutnya siswa diberikan soal yang berkaitan dengan materi sebagai bentuk evaluasi. Adapun hasil belajar yang didapat sebelum perbaikan adalah sebagai berikut :

Tabel 1. Hasil Belajar Siswa Prasiklus

\begin{tabular}{clc}
\hline No & \multicolumn{1}{c}{ Uraian } & Hasil Prasiklus \\
\hline 1 & Persentase Ketuntasan belajar & $29 \%$ \\
2 & Nilai rata-rata tes hasil belajar & 54,05 \\
3 & Jumlah peserta didik yang tuntas belajar & 6 \\
4 & Jumlah peserta didik yang tidak tuntas belajar & 15 \\
5 & Nilai terbesar & 80 \\
6 & Nilai Terkecil & 20 \\
\hline
\end{tabular}

Dilihat dari data di atas dapat diketahui bahwa hasil belajar rata - rata siswa tergolong relatif rendah, rendahnya hasil belajar banyak faktor penyebabnya salah satunya yaitu kemampuan dasar yang dimiliki siswa sangat rendah, guru menggunakan pembelajaran yang bersifat kovensional (ceramah), sehingga pembelajaran kurang menarik, guru sering mengabaikan penggunaan media pembelajaran yang dapat 
Vol. 1 No. 1 Mei 2021

meningkatkan kemampuan dasar, dan siswa cenderung pasif dalam kegiatan pembelajaran berlangsung.

Melihat hasil di atas dari 21 orang siswa hanya 6 orang yang nilainya diatas standar maksimal KKM 70 atau hanya 29\%, maka harus diadakan perbaikan pembelajaran. Pada siklus I peneliti menggunakan media video animasi yang disampaikan dengan menggunakan sharescreen, sebagian siswa menunjukkan sedikit antusias dan semangat saat guru memberikan materi pelajaran pada siswa.

Pada siklus I ini guru memberikan kesempatan kepada siswa untuk melakukan tanya jawab dengan guru serta sesama siswa dengan menggunakan diskusi daring, setelah itu guru memberikan tugas. Dari hasil evaluasi ternyata ada sedikit peningkatan, peningkatan ini tercermin dari beberapa siswa dalam mengikuti pelajaran yang lebih termovitasi dan bersemangat dalam mengikuti proses belajar mengajar serta diikuti dengan sikap siswa yang tidak lagi mengantuk.

Tabel 2. Hasil Belajar Siswa Siklus I

\begin{tabular}{clc}
\hline No & \multicolumn{1}{c}{ Uraian } & Hasil Siklus I \\
\hline 1 & Persentase Ketuntasan belajar & $67 \%$ \\
2 & Nilai rata-rata tes hasil belajar & 70,24 \\
3 & Jumlah peserta didik yang tuntas belajar & 14 \\
4 & Jumlah peserta didik yang tidak tuntas belajar & 7 \\
5 & Nilai terbesar & 100 \\
6 & Nilai Terkecil & 50 \\
\hline
\end{tabular}

Setelah siklus I dilaksanakan dengan hasil belum sesuai dengan yang diharapkan walaupun tingkat keberhasilan siswa bertambah dan motivasi meningkat dari sebelum perbaikan. Maka peneliti melakukan siklus II sebagai tindakan perbaikan.

Tabel 3. Hasil Belajar Siswa Siklus II

\begin{tabular}{clc}
\hline No & \multicolumn{1}{c}{ Uraian } & Hasil Siklus II \\
\hline 1 & Persentase Ketuntasan belajar & $86 \%$ \\
2 & Nilai rata-rata tes hasil belajar & 83,57 \\
3 & Jumlah peserta didik yang tuntas belajar & 18 \\
4 & Jumlah peserta didik yang tidak tuntas belajar & 3 \\
5 & Nilai terbesar & 100 \\
6 & Nilai Terkecil & 60 \\
\hline
\end{tabular}

Pada siklus II media yang digunakan yaitu video animasi untuk meningkatkan prestasi belajar Matematika Kelas VI SD Negeri 32 Prabumulih Kecamatan Prabumulih Barat sehingga siswa dapat termotivasi dalam belajar. Dalam hal ini terbukti dengan adanya peningkatan motivasi belajar siswa. Banyak faktor penyebabnya antara lain media yang digunakan adalah media video animasi yang disukai anak-anak, video bergerak dan bersuara dengan warna yang kontras menarik minat anak, serta cara guru menyampaikan pelajaran serta menghadapi siswa dalam belajar, Hal ini menarik perhatian, menumbuhkan semangat dan menimbulkan kesan yang positif sehingga siswa termotivasi untuk belajar dengan serius.

Setelah diadakan perbaikan pembelajaran siklus II ini mengalami peningkatan yang relatif tinggi yaitu dari 21 orang siswa, 18 orang siswa yang sudah di atas KKM atau mencapai 86\%. Pada Penelitian Tindakan Kelas (PTK) ini banyak sekali hal yang ditemukan oleh peneliti. Hal ini berkaitan erat dengan kemajuan peneliti. Untuk melakukan penelitian dan peningkatan hasil belajar siswa dilakukan dengan mengunakan 
Vol. 1 No. 1 Mei 2021

media video, metode yang lebih bervariatif yaitu diskusi kelompok di bantú aplikasi whatsap, peneliti juga menekankan pada kemampuan dan memberikan penguatan serta memberikan pertanyaan yang dapat memotivasi siswa.

Sebelumnya siswa diberikan materi dengan metode ceramah selanjutnya diberikan evaluasi. Pada siklus ini siswa tidak mengalami kesulitan yang berarti tetapi siswa terlihat pasif dan beberapa siswa ngobrol pada saat materi diberikan.

Pada siklus I siswa mulai diberikan tindakan dengan memberikan kegiatan tugas. Namun ketika kegiatan berlangsung siswa nampak aktif dan antusias sekali dalam mengerjakan tugas yang diberikan keadaan yang sama dirasakan peneliti pada siklus II semangat siswa belajar sangat tinggi, proses pembelajaran terasa interaktif antara siswa dan guru.

Tabel 4. Aktivitas Belajar Siswa

\begin{tabular}{cccccccc}
\hline \multirow{2}{*}{ No } & $\begin{array}{c}\text { Keterlibatan } \\
\text { peserta didik } \\
\text { dalam }\end{array}$ & \multicolumn{2}{c}{ Prasiklus } & \multicolumn{2}{c}{ Siklus I } & \multicolumn{2}{c}{ Siklus II } \\
\cline { 3 - 8 } & $\begin{array}{c}\text { Jumlah } \\
\text { pembelajaran }\end{array}$ & Siswa & $\%$ & $\begin{array}{c}\text { Jumlah } \\
\text { Siswa }\end{array}$ & $\%$ & $\begin{array}{c}\text { Jumlah } \\
\text { Siswa }\end{array}$ & $\%$ \\
\hline 1 & Terlibat Aktif & 6 & $28,6 \%$ & 10 & $47,6 \%$ & 18 & $85,7 \%$ \\
2 & Terlibat Pasif & 8 & $38,1 \%$ & 8 & $38,1 \%$ & 3 & $14,3 \%$ \\
3 & Tidak Terlibat & 7 & $33,3 \%$ & 3 & $14,3 \%$ & 0 & $0 \%$ \\
\hline & Jumlah & $\mathbf{2 1}$ & $\mathbf{1 0 0 \%}$ & $\mathbf{2 1}$ & $\mathbf{1 0 0 \%}$ & $\mathbf{2 1}$ & $\mathbf{1 0 0 \%}$ \\
\hline
\end{tabular}

Berdasarkan tabel di atas terlihat bahwa jumlah siswa dan persentase siswa yang terlibat aktif dalam pembelajaran sebelum perbaikan pembelajaran dan setelah perbaikan pembelajaran menunjukkan adanya peningkatan. Sebelum perbaikan pembelajaran siswa yang terlibat aktif 6 orang $(28,6 \%)$, kemudian meningkat jadi 10 orang $(47,6 \%)$ pada siklus I. Pada siklus II menjadi 18 orang $(85,7 \%)$.

Keadaan siswa yang belajar dengan aktif, semangat dan interaktif ini dapat berpengaruh pada hasil belajar siswa. Hal ini dapat dilihat dari hasil pengamatan peneliti mengenai motivasi siswa dan meningkatnya hasil belajar siswa.

\section{b. Pembahasan}

Hal yang ditemukan oleh peneliti pada awal siklus sangat berpengaruh pada siklus selanjutnya. Seperti yang dikemukakan sebelumnya siklus I siswa terlibat kurang bersemangat, pasif dan cenderung tak memperhatikan pelajaran sehingga hasil belajar siswa rendah. Hal ini membuat peneliti mencari solusinya, agar dapat mengetahui cara yang tepat untuk memperbaiki pembelajaran pada siklus berikutnya.

Setelah diadakan Penelitian Tindakan Kelas (PTK) pada siklus II di kelas VI SD Negeri 32 Prabumulih Kecamatan Prabumulih Barat, peneliti merasa optimis dengan motivasi siswa yang tinggi dapat meningkatkan hasil belajar hal ini dilakukan dengan cara pengunaan media videoanimasi dan metode diskusi daring yang melibatkan siswa secara langsung sehingga siswa dapat berperan aktif dalam pembelajaran dan harus ada kerja sama antara siswa, guru pihak sekolah untuk meningkatkan kualitas mutu belajar sekolah.

Berkaitan dengan media animasi, animasi merupakan suatu bentuk presentasi bergambar yang paling menarik, yang berupa simulasi gambar bergerak yang menggambarkan perpindahan atau pergerakan suatu objek (Mayer dan Moreno, 2002; Sukiyasa dan Sukoco, 2013). Pemggunaan animasi dalam proses pembelajaran sangat membantu dalam meningkatkan efektifitas dan efisiensi proses pengajaran, serta hasil pembelajaran yang meningkat. Selain itu penggunaan media pembelajaran khususnya 
animasi dapat meningkatkan daya Tarik, serta motivasi siswa dalam mengikuti proses pembelajaran. (Sukiyasa dan Sukoco, 2013).

Berdasarkan hasil observasi dan evaluasi belajar siswa pada mata pelajaran Matematika materi Operasi Hitung Pecahan sebelum dilakukan perbaikan dan setelah dilakukan perbaikan pembelajaran siklus I dan siklus II mengalami peningkatan. Peningkatan hasil belajar siswa ini dipengaruhi oleh penggunaan metode diskusi daring dengan media video animasi.

Hasil belajar siswa sebelum dilakukan perbaikan hanya 6 orang (29\%), pada perbaikan pembelajaran siklus I meningkat menjadi 14 orang $(67 \%)$ dan pada perbaikan pembelajaran siklus II mengalami peningkatan menjadi 18 orang (86\%). Hal ini menunjukkan bahwa penggunaan media video animasi dan metode diskusi daring dapat meningkatkan hasil belajar siswa kelas VI SD Negeri 32 Prabumulih.

Hal ini sesuai dengan yang dikatakan oleh Liza Yunita, dalam penelitiannya, suatu pembelajaran dikatakan berhasil apabila sekurang-kurangnya 75\% dari jumlah siswa telah memperoleh nilai 70 dalam peningkatan hasil belajar. Pembelajaran dikatakan efektif apabila secara statistik hasil belajar siswa menunjukkan perbedaan yang signifikan antara pengetahuan awal dengan pengetahuan setelah pembelajaran (Yunita, 2017).

Adapun permasalahan yang terjadi saat penelitian yaitu pada saat pelaksanaan pembelajaran dengan menggunakan metode diskusi daring. Ada beberapa siswa mengalami kendala untuk membuka aplikasi whatsapp karena hp digunakan sembari zoom meeting. Untuk mengatasi hal ini guru meminta bantuan orang tua untuk mendukung dalam hal pemfasilitasan Smartphone dan laptop pada masing-masing siswa.

Selain itu menurut beberapa siswa, video aminasi yang ditayangkan terlalu cepat sehingga ada beberapa pertanyaan yang belum sempat terjawab. Peneliti dapat menyelesaikan masalah ini dengan cara menayangkan ulang video animasi.

Permasalahan selanjutnya yaitu pada saat video animasi telah selesai ditampilkan. Ada beberapa siswa yang sibuk sendiri, ada yang menggunakan Smartphone nya untuk chat bersama teman-temannya di kelompok whatsapp. Permasalahan ini dapat diatasi dengan mengadakan tanya jawab berkaitan dengan materi pembelajaran. Disamping itu guru dapat menegur langsung siswa yang terlihat tidak konsentrasi tersebut sehingga dapat melanjutkan pembelajaran dengan fokus kembali.

\section{KESIMPULAN}

Berdasarkan hasil penelitian dan pembahasan, dapat disimpulkan bahwa penggunaan media video animasi dalam pembelajaran matematika materi operasi hitung pecahan dapat meningkatkan hasil belajar siswa kelas VI SDN 32 Prabumulih.Peningkatan hasil belajar siswa dapat dilihat dari rata-rata hasil post test pada masing-masing siklus. Rata-rata hasil post test terjadi peningkatan dari 70,24 pada siklus I menjadi 83,57 pada siklus II. Persentase ketuntasan belajar juga mengalami peningkatan dari $67 \%$ pada siklus I menjadi $86 \%$ pada siklus II. Selain itu, persentase siswa yang terlibat aktif juga mengalami peningkatan dari $47,6 \%$ pada siklus I menjadi $85,7 \%$ pada siklus II.

\section{DAFTAR PUSTAKA}

Deporter, B \& Hernacki. (2005). Quantum Learning. Bandung: Kaifa

Ferry, dkk. (2019). Peningkatan Hasil Belajar Biologi Siswa Melalui Penerapan Media Video

Animasi Tiga Dimensi (3D). J. Pedagogi Hayati.3(2), 1-11.

Kemmis, S. \& McTaggart, R. (1988). The action Research Planner. Victoria: Deakin University Press. 
Mayer, R.E \& Moreno, R. (2002). Animation as an aid multimedia learning. Educational psychology review.14(1), 87-99.

Nurhasanah, Siti dan Sobandi. (2016). Minat Belajar Sebagai Determinan Hasil belajar. Jurnal Pendidikan Manajemen Perkantoran (JPManper).1(1), 128-135.

Nusir, s., alsmadi, i., Al-kabi, m., \& sharadgah, f. (2012). Studying the impact of using multimedia interacktive programs at children ability to learn basic math skills. Acta Didactica Napocensia.5(2), 17-31.

Somawati, Ni Wayan. (2021). Penerapan Model Pembelajaran Group Investigation untuk Meningkatkan Hasil Belajar Peserta Didik kelas IX.4 semester I SMP Negeri I Banjarangkan Tahun Pelajaran 2019/2020. Jurnal inovasi penelitian pendidikan dan pembelajaran.1(1), 1-8.

Sudjana, N \& Rivai, A. (2005). Media Pengajaran. Bandung: Sinar Baru Algesindo.

Sukiyasa, K \& Sukoco. 2013. Pengaruh Media Animasi Terhadap Hasil Belajar dan Motivasi Belajar Siswa Materi Sistem Kelistrikan Otomotif.Jurnal Pendidikan Vokasi.3(1), 126137.

W. S. Anwar, W. Liliawati, J. A. Utama. (2013). Penerapan Pembelajaran konseptual Interaktif dengan menggunakan Media Animasi Untuk Meningkatkan Penguasaan konsep IPBA dan Mengetahui Profil Aktivitas Siswa SMP. Jurnal Wahana Pendidikan Fisika.1.(1), 37-47.

Yunita, L. 2017. Pengaruh Penggunaan Media Animasi Terhadap Aktivitas Dan Hasil Belajar Siswa Pada Materi Sistem Pencernaan di SMP 1 Darussalam. Skripsi. Banda Aceh : Fakultas Tarbiyah Dan Keguruan Universitas Islam Negeri Ar-Raniry Darussalam. 